\title{
KEPEMIMPINAN PEMERINTAHAN TERHADAP PENINGKATAN PARTISIPASI MASYARAKAT PADA MUSYAWARAH PERENCANAAN PEMBANGUNAN DI DESA BETAO KECAMATAN PITU RIAWA KABUPATEN SIDENRENG RAPPANG
}

\author{
Herman D. ${ }^{1}$, Ratna $^{2}$ \\ Fakultas IImu Sosial dan IImu Politik, Universitas Muhammadiyah Rappang \\ e-mail: hermandema1010@gmail.com \\ Ratna 43151008g1@gmail.com
}

\begin{abstract}
Abstrak
Penelitian ini bertujuan untuk mengetahui : (1) Kepemimpinan di Desa Betao Kecamatan Pitu Riawa Kabupaten Sidenreng Rappang (2) Partisipasi masyarakat pada musyawarah perencanaan pembangunan di Desa Betao Kecamatan Pitu Riawa Kabupaten Sidenreng Rappang. (3) Kepemimpinan pemerintahan terhadap peningkatan partisipasi masyarakat pada musyawarah Perencanaan pembangunan di Desa Betao Kecamatan Pitu Riawa Kabupaten Sidenreng Rappang. Penelitian ini merupakan penelitian kuantitatif menggunakan analisis deskriptif. Populasi dalam penelitian ini sebanyak 72 orang yaitu BPD (Badan Permusyawaratan Desa), anggota PKK, Kepala Dusun, Kelompok Tani, Tokoh Agama,Tokoh Pemuda, dan Tokoh masyarakat.Pengambilan sample menggunakan sample jenuh yang teknik penentuan sampel bila semua anggota populasi digunakan sebagai sampel. Teknik pengumpulan data dalam penelitian ini menggunakan (1) observasi, (2) wawancara, (3)kousioner (4) Study Kepustakaan. Teknik analisis data menggunakan skala likert dengan bantuan tabel frekuensi dan program SPSS (Statistical Product and Service Solution) versi 16,0. Hasil penelitian menunjukkkan bahwa kepemimpinan di Desa Betao Kecamatan Pitu RiawaKabupaten Sidenreng Rappang dengan Nilai 49,46 \% dengan kategori "Cukup Baik". Sedangkan indikator partisipasi Masyarakat dengan Nilai $62,56 \%$ atau kategori "Terlaksana dengan Baik". Kemudian Kepemimpinan Pemerintahan Terhadap Peningkatan Partisipasi Masyarakat Pada Musyawarah Perencanaan Pembangunan di Desa Betao Kecamatan Pitu Riawa Kabupaten Sidenreng Rappang dengan nilai $t$ hitung $>t$ tabel, atau9.850>1,99 dengan tingkat signifikan 0,00 atau lebih kecil dari 0,05 atau dikategorikan signifikan.
\end{abstract}

Kata Kunci : Partisipasi Masyarakat dan Kepemimpinan

\section{Abstract}

This study aims to determine: (1) Leadership of Village Heads in Betao Village, Pitu Riawa Sub-District, Sidenreng Rappang Regency (2) Community Participation in the Development Planning Conference in Betao Village, Pitu Riawa District, Sidenreng Rappang District. (3) Government Leadership towards Increased Community Participation in Delivering Development Planning in Betao Village, Pitu Riawa District, Sidenreng Rappang Regency. This research is a quantitative research using descriptive analysis. The population in this study were 72 people, namely BPD (Village Consultative Body), PKK Members, Hamlet Heads, Farmer Groups, Religious Leaders, Youth Figures, and Community Leaders. Sampling uses saturated samples for sampling techniques if all members of the population are used as samples. Data collection techniques in this study used (1) observation, (2) interviews, (3) questionnaires. The data analysis technique uses a Likert scale with the help of the frequency table and the SPSS program (Statistical Product and Service Solution) version 16.0. The results showed that the leadership of the Head of the Village in Betao Village, Pitu Subdistrict, the District of Sidenreng Rappang with a percentage value of

PRAJA | Volume 8| Nomor 2| Edisi Juni 2020 
$49.46 \%$ with a category of "Fairly Good". While the indicator of community participation with a percentage value of $62,6 \%$ with the category " well implemented" Then government leadership on increasing community participation in Betao Village Pitu Riawa District, Sidenreng Rappang with value $t$ count $>t$ table, or $9.850>1.99$ with a significant level of 0.00 or smaller than 0.05 or categorized as significant.

Keywords: Community Participation and Leadership.

PRAJA | Volume 8| Nomor 2| Edisi Juni 2020 


\section{A. PENDAhULUAN}

Sesuai dengan ketentuan undangundang No 6 Tahun 2014 Tentang Desa yang berlaku dalam sistem pemerintahan Indonesia, bahwa Kepala Desa adalah Kepala Pemerintahan Desa yang bertugas menyelenggarakan pemerintahan desa, melaksanakan pembangunan desa, Pembinaan kemasyarakatan desa, dan Pemberdayaan desa. Maka salah satu tugas Seorang Kepala Desa adalah melaksanakan pembangunan. Pembangunan wilayah pendesaan mengarah pada peningkatan kesejahteraan masyarakat melalui pedesaan sebagai usaha mempercepat pembangunan pedesaan melalui penyediaan sarana dan prasarana agar tercipta ekonomi daerah yang efektif. Pembangunan dilakukan guna menunjang dan meningkatkan mutu kehidupan masyarakat kearah yang lebih baik, masyarakat tidak bertindak sendiri dalam pelaksanaan pembangunan, tetapi masyarakat di atur dan dikendalikan oleh pemerintah agar tidak terjadi penyalahgunaan dan tumpang tindih dalam pembangunan.Pemerintah desa sebagai bahan eksekutif berfungsi menjalangkan fungsi pemerintah, pembangunan dan menciptakan kehidupan yang harmonis di desa, untuk dapat menjalangkan perannya secara efektif dan efisien.

Kepemimpinan adalah kemampuan untuk mempengaruhi orang lain untuk mencapai tujuan dengan atusias, dan mampu memberikan contoh kepada pengikut-pengikutnya lewat proses komunikasi terhadap upaya mencapai tujuan organisasi. Pada sebuah organisasi pemerintahan kesuksesan atau kegagalan dalam pelaksanaa pelayaan masyarakat, dipengaruhi oleh kepemimpinan, melalui kepemimpinan dan didukung oleh pemerintahan yang memadai, maka penyelenggaraan tata pemerintahan yang baik akan terwujud sebaliknya kelemahan kepemimpinan merupakan salah satu sebab keutuhan kinerja birokrasi Indonesia (Istianto,2011), Dalam pembangunan, partisipasi masyarakat merupakan salah satu elemen proses pembangunan desa, oleh karena itu partisipasi masyarakat dalam pembangunan perlu dibangkitkan terlebih dahulu oleh pihak lain seperti pemerintahan desa atau kepala desa, sehingga dengan adanya keterlibatan pemerintah desa besar kemungkinan masyarakat akan merasa di beri peluang atau kesempatan ikut serta dalam pembangunan, karena pada dasarnya menggerakkan partisipasi masyarakat desa merupakan salah satu sasaran pembangunan desa itu sendiri.

Menurut Sumardi dan Evers ( Sahya Anggara, 2014: 224) partisispasi masyarakat dalam pembangunan merupakan kebutuhan dasar seperti kebutuhan sandang, papan, pendidikan, kesehatan, dan transportasi. Menurut Sumardi dalam Zainunddin (2017:283) bahwa partisipasi adalah peran serta seseorang atau kelompok masyarakat dalam proses pembangunan baik dalam bentiuk perrnyataan maupun dalam bentuk kegiatan dengan memberi masukan pikiran, tengah, waktu, keahlian, modal, dan atau materi, serta ikut memanfaatkan dan menikmati hasil-hasil pembangunan. Partisipasi masyarakat merupakan modal utama dalam upaya mencapai sasaran program pemerintahan diseluruh wilayah Republik Indonesia. Keberhasilan dalam pencapaian sasaran pelaksanaan program pembangunan bukan semata-mata didasarkan pada kemampuan aparatur pemerintahan, tetapi juga berkaitan dengan upaya mewujudkan kemampuan dan keamanan masyarakat untuk berpartisipasi dalam pelaksanaan program pembangunan. Adanya partisipasi masyarakat akan mampu mengimbangi keterbatasan biaya dan kemampuan pemerintah dalam pencapaian pelaksanaan program pembangunan tersebut.

Namun ada sebagian anggota masyarakat dapat membantu dalam hal memberikan sumbangan pandangan, pikiran dan tenaga. Kesediaan masyarakat untuk membantu berhasilnya setiap program sesuai dengan kemampuan setiap orang tanpa berarti mengorbankan kepentingan diri sendiri. Tentu saja partisipasi seperti ini suatu tanda permulaan tumbuhnya masyarakat 
yang mampu berkembang secara mandiri. Jika dikaitkan dengan pembangunan di Desa Betao, partisispasi masyarakat merupakan hal yang sangat penting bahkan sulit dipisahkan karena ini sangat berpengaruh pada cepat lambatnya kemajuan pembangunan di Desa Betao khususnya dalam hal pembangunan fisik, Dalam pembangunan, partisipasi masyarakat merupakan salah satu elemen proses pembangunan desa, oleh karena itu partisipasi masyarakat dalam pembangunan perlu dibangkitka terlebih dahulu oleh pihak lain seperti pemerintah desa atau kepala desa, sehingga dengan adanya keterlibatan pemerintahan desa besar kemungkinan masyarakat akan merasakan diberi peluang atau kesempatan ikut serta dalam pembangunan, karena pada sasarnya menggerakan partisipasi masyarakat desa merupakan salah satu sasaran pembangunan desa itu sendiri.

Pentingnya keterlibatan masyarakat di dalam penyusunan perencanaan pembangunan sangat ditekankan dalam Undang-Undang Nomor 23 Tahun 2014 psaal 354 ayat 1 bahwa untuk mendorong partisipasi masyarakat maka pemerintahan daerah (a) menyampaikan informasi tentang penyelenggaraan Pemerintahan kepada masyarakat, (b) mendorong kelompok dan organisasi masyarakat untuk berperan aktif dalam penyelenggaraan Pemerintahan Daerah melalui dukungan pengembangan kapasitas masyarakat, (c) mengembangkan kelembagaan dan mekanisme pengambilan keputusan yang memungkinkan kelompok dan organisasi masyarakat dapat terlibat secara aktif, dan atau kegiatan lainnya sesuai dengan ketentuan peraturan undan-undang . Dengan adanya program-program partisipasif memberikan kesempatan secara langsung kepada masyarakat untuk berpartisipasi dalam rencana yang menyangkut kesejahteraan mereka dan secara langsung juga melaksanakan sendiri seraya memetik hasil program tersebut. Partisipasi masyarakat dalam pembangunan saat ini masih pada tahap perencanaan atau dalam kegiatan MUSREMBANG (Musyawarah
Perencanaan Pembangunan), oleh karena itu banyak masyrakat yang beranggapan bahwa pembangunan hanya merupakan tigas da tanggung jawab pemerintah. Partisipasi masyarakat dalam pembangunan tidak dapat dilihat hanya dari keikutsertaan masyarakat dalam kegiatan MUSREMBANG, namun juga dilihatdari beberapa lingkup yaitu partisipasimasyarakat dalam pelaksanaan kegiatan pembangunan, partisipasi dalam pengevaluasian pelaksanaan pembangunan serta partisipasi dalam pemanfaatan hasil pembangunan, Dalam mewujudkan tujuan program pembangunan pada setiap lembaga dibutuhkan suatu pola manjerial dalam pengelolaan pembangunan, pola manajerial tersebut dimaksudkan agar hasil pembangunan dan program-program pemerintahan lainnya dapat dirasakan dan dinikmati manfaatnya oleh masyarakat. Pemberian kesempatan berpartisipasi dalam pembangunan harus ditanamkan dalam diri masyarakat bahwa masyarakat layak diberi kesempatan, karena masyarakat mempunyai hak untuk berpartisipasi dalam setiap kegiatan pembangunan yang ada.Masalah yang di dapat saat observasi di kantor desa betao yaitu, kurangnya dukungan masyarakat terhadap program pembangunan desa, hal ini dapat dibuktikan dengan kurangnya masyarakat yang mengikuti kegiatan musrenbang, dari 72 orang yang diundang mengikuti kegiatan musrembang yang hadir hanya sekitar $15-20$ orang. Dan masyarakat yang hadir kurang memberikan saran/masukan kepada pemerintah desa sedangkan masyarakat yang lebih mengetahui tentang kebutuhan setiap lingkungan, sehingga program pembangunan di putuskan oleh pemerintah desa. Sehingga pembangunan menjadi tidak berjalan efektif dan efisien. Hal ini diketahui dari observasi yang dilakukan pada Bulan Oktober tanggal 28 sampai 30 Oktober 2018 di Desa Betao.

Kepala desa merupakan jabatan resmi yang dimiliki seseorang dalam kemampuanya meliputi proses mempengaruhi orang lain dalam menentukan tujuan organisasi, memotivasi perilaku pengikut atau 
mencapai tujuan, mmepengaruhi untuk memperbaiki kelompok dan budayanya (Yuliandra 2013), menurut Surur (2013) kepala desa juga seharusnya berperan dalam membangun kesadaran masyarakat untuk berpasrtisipasi terhadap program-program yang dilakukan oleh pemerintah desa. Berdasarkan uraian di atas, penulis tertarik untuk melakukan penelitian dan penulisan skripsi dengan judul Kepemimpinan Pemerintahan terhadap Peningkatan Partisispasi Masyarakat pada musyawarah perencanaan Pembangunan di Desa Betao Kecamatan Pitu Riawa Kabupaten Sidenreng Rappang dengan tujuan untuk mengetahuikepemimpinan Kepala Desadalam meningkatkan Partisipasi masyarakat pada musyawarah perencanaan di Desa Betao Kecamatan Pitu Riawa Kabupaten Sidenreng Rappang, untuk mengetahui partisipasi masyarakat pada musyawarah perencanaan pembangunan di Desa Betao Kecamatan Pitu Riawa Kabupaten Sidenreng Rappang dan untuk mengetahuikepemimpinan pemerintahan terhadap partisipasi masyarakat pada musyawarah perencanaan pembangunan di Desa Betao Kecamatan Pitu Riawa Kabupaten Sidenreng Rappang.

\section{Konsep Kepemimpinan}

Kepemimpinan adalah salah fungsi Manajemen untuk mempengaruhi, mengarahkan, memotivasi dan mengawasi orang lain agar dapat melakukan tugas-tugas yang telah direncanakan sehingga mencapai sasaran dan tujuan organisasinya. Kemampuan kepemimpinan atau Leadership seorang Manajer akan sangat mempengaruhi kinerja organisasi terutama dalam hal pencapaian tujuan organisasinya. Ada banyak ahli manajemen yang merumuskan definisi-definisi tentang Kepemimpinan atau Leadership ini. Salah satu diantaranya adalah definisi Kepemimpinan menurut Gareth Jones and Jennifer George (2010:440). Menurutnya, kepemimpinan adalah proses dimana seorang individu mempunyai pengaruh terhadap orang lain dan mengilhami, memberi semangat, memotivasi dan mengarahkan kegiatan-kegiatan mereka guna membantu tercapai tujuan kelompok atau organisasi.

$$
\text { Menurut Rivai }
$$

Kepemimpinan adalah seorang pemimpin dalam proses mengarahkan dan mempengaruhi aktivitas-aktivitas yang ada hubungannya dengan pekerjaan para anggota kelompok.Menurut George R. Terry dalam Veithzal Rivai (2014:3) kepemimpinan adalah kegiatan mempengaruhi orang-orang untuk bersedia berusaha mencapai tujuan bersama. Sedangkan menurut Thoha dalam Veithzal Rivai (2014:4) kepemimpinan adalah aktivitas untuk mempengaruhi perilaku orang lain agar supaya mereka mau diarahkan untuk mencapai tujuan tertentu. Menurut Stephen P. Robbins (2011:40), Kepemimpinan adalah kemampuan untuk mempengaruhi suatu kelompok ke arah tercapainya tujuan. Sedangkan definisi Kepemimpinan menurut Richard L. Daft (2011:50) adalah Kemampuan mempengaruhi orang yang mengarah kepada pencapaian tujuan.Dari beberapa definisi tersebut, sangat jelas dikatakan bahwa kepemimpinan adalah fungsi manajemen yang erat keterkaitannya dengan pencapaian tujuan organisasi.

$$
\text { Hause terhadap Zainuddin }
$$
(2017:233), mengemukakan bahwa kepemimpinan terhadap kemampuan individu untuk mempengaruhi,memotifasi dan membuat orang lain mampu memberikan kontribusinya demi efektifitas dan keberhasilan organisasi. Sedangkan Terry menyatakan bahwa kepemimpinan adalah kegiatan terhadap mempengaruhi orang lain untuk bekerja keras dengan penuh kemampuan untuk tujuan kelompok. Stigdill dalam (Zainuddin, 2017 : 234) , merumuskan bahwa kepemimpinan adalah suatu proses mengarahkan dan mempengaruhi aktifitas yang berkaitan dengan pekerjaan dan anggota kelompok. Kartini Kartono (2014:47), bahwa pemimpinan adalah seseorang pribadi yang memiliki kecakapan-kecakapan dan kelebihankelebihan. Kecakapan dan kelebihan ini yang dimaksudkan agar pemimpin itu mampu mempengaruhi orang lain untuk 
bersama-sama melakukan aktivitas tertentu demi pencapaian tujuan.

Allah berfirman dalam (QS. AnNisaa : 58) sebagai berikut:

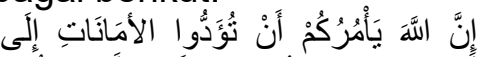

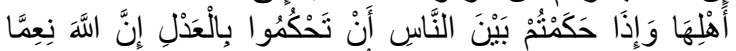

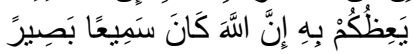

Artinya :

Sesungguhnya Allah menyuruh kamu menyampaikan amanat kepada yang berhak menerimanya, dan (menyuruh kamu) apabila menetapkan hukum di antara manusia supaya kamu menetapkan dengan adil.Sesungguhnya Allah memberi pengajaran yang sebaikbaiknya kepadamu. Sesungguhnya Allah adalah Maha mendengar lagi Maha melihat." (QS. An-Nisa': 58)

Orang yang melakukan fungsi kepemimpinan ini biasanya disebut dengan "pemimpin" atau dalam bahasa Inggris disebut dengan "Leader". Berdasarkan definisi dari Ricky W. Griffin (2010:68), Pemimpin adalah individu yang mampun mempengaruhi perilaku orang lain tanpa harus mengandalkan kekerasanpemimpin adalah individu yang diterima oleh orang lain sebagai pemimpin.

a. Kepemimpinan Otokratis

Pemimpin sangat dominan dalam setiap pengambilan keputusan dan setiap kebijakan, peraturan, prosedur diambil dari idenya sendiri.Kepemimpinan jenis ini memusatkan kekuasaan pada dirinya sendiri.la membatasi inisiatif dan daya pikir dari para anggotanya. Pemimpin yang otoriter tidak akan memperhatikan kebutuhan dari bawahannya dan cenderung berkomunikasi satu arah yaitu dari atas (pemimpin) ke bawah (anggota). Jenis kepemimpinan ini biasanya dapat kita temukan di akademi kemiliteran dan kepolisian.

b. Kepemimpinan Birokrasi

Gaya kepemimpinan ini biasa diterapkan dalam sebuah perusahaan dan akan efektif apabila setiap karyawan mengikuti setiap alur prosedur dan melakukan tanggung jawab rutin setiap hari.Tetap saja dalam gaya kepemimpinan ini tidak ada ruang bagi para anggota untuk melakukan inovasi karena semuanya sudah diatur dalam sebuah tatanan prosedur yang harus dipatuhi oleh setiap lapisan.

c. Kepemimpinan Partisipatif

Gaya kepemimpinan partisipatif, ide dapat mengalir dari bawah (anggota) karena posisi kontrol atas pemecahan suatu masalah dan pembuatan keputusan dipegang secara bergantian.Pemimpin memberikan ruang gerak bagi para bawahan untuk dapat berpartisipasi dalam pembuatan suatu keputusan serta adanya suasana persahabatan dan hubungan saling percaya antar pimpinan dan anggota.

d. Kepemimpinan Delegatif

Gaya kepemimpinan ini biasa disebut Laissez-faire dimana pemimpin memberikan kebebasan secara mutlak kepada para anggota untuk melakukan tujuan dan cara mereka masing-masing. Pemimpin cenderung membiarkan keputusan dibuat oleh siapa saja dalam kelompok sehingga terkadang membuat semangat kerja tim pada umumnya menjadi rendah.Jenis kepemimpinan ini akan sangat merugikan apabila para anggota belum cukup matang dalam melaksanakan tanggung jawabnya dan memiliki motivasi tinggi terhadap pekerjaan.Namun sebaliknya dapat menjadi boomerang bagi perusahaan bila memiliki karyawan yang bertolak belakang dari pernyataan sebelumnya.

e. Kepemimpinan Transaksional

Kepemimpinan jenis ini cenderung terdapat aksi transaksi antara pemimpin dan bawahan dimana pemimpin akan memberikan reward ketika bawahan berhasil melaksanakan tugas yang telah diselesaikan sesuai kesepakatan. Pemimpin dan bawahan memiliki tujuan, kebutuhan dan kepentingan masingmasing.

f. Kepemimpinan Transformasional

Gaya kepemimpinan transformasional dapat menginspirasi perubahan positif pada mereka (anggota) yang mengikuti. Para pemimpin jenis ini memperhatikan dan terlibat langsung dalam proses termasuk dalam hal membantu para anggota kelompok untuk berhasil menyelesaikan tugas mereka.

Pemimpin cenderung memiliki semangat yang positif untuk para 
bawahannya sehingga semangatnya tersebut dapat berpengaruh pada para anggotanya untuk lebih energik. Pemimpin akan sangat mempedulikan kesejahteraan dan kemajuan setiap anak buahnya.

g. Kepemimpinan Melayani (Servant)

Hubungan yang terjalin antara pemimpin yang melayani dengan para anggota berorientasi pada sifat melayani dengan standar moral spiritual.Pemimpin yang melayani lebih mengutamakan kebutuhan, kepentingan dan aspirasi dari para anggota daripada kepentingan pribadinya.

h. Kepemimpinan Karismatik

Pemimpin yang karismatik memiliki pengaruh yang kuat atas para pengikut oleh karena karisma dan kepercayaan diri yang ditampilkan para pengikut cenderung mengikuti pemimpin karismatik karena kagum dan secara emosional percaya dan ingin berkontribusi bersama dengan pemimpin karismatik.Karisma tersebut timbul dari setiap kemampuan yang mempesona yang ia miliki terutama dalam meyakinkan setiap anggotanya untuk mengikuti setiap arahan yang ia inginkan.

i. Kepemimpinan Situasional

Pemimpin yang menerapkan jenis kepemimpinan situasional lebih sering menyesuaikan setiap gaya kepemimpinan yang ada dengan tahap perkembangan para anggota yakni sejauh mana kesiapan dari para anggota melaksanakan setiap tugas. gaya kepemimpinan situasional mencoba mengkombinasikan proses kepemimpinan dengan situasi dan kondisi yang ada. setidaknya ada 4 gaya yang diterapkan oleh pemimpin jenis ini, diantaranya:
1) Telling-Directing menunjukkan,
(memberitahu, memimpin, menetapkan).
2) Selling-Coaching menjelaskan, membujuk),
(menjual, memperjelas,
3) Participating-Supporting (mengikutsertakan, memberi semangat, kerja sama),
4) Delegating pengamatan, penyelesaian).

Menurut Wahjosumidjo (Wijayanti, 2012), secara garis besar indikator kepemimpinan adalah sebagai berikut:

a. Bersifat adil. Kegiatan suatu organisasi, rasa kebersamaan diantara para anggota adalah mutlak, sebab rasa kebersamaan pada hakikatnya merupakan pencerminan dari pada kesepakatan antara para bawahan maupun antara pemimpin dengan bawahan dalam mencapai tujuan organisasi.

b. Memberi sugesti. Sugesti biasanya disebut sebagai saran atau anjuran. Dalam rangka kepemimpinan, sugesti merupakan pengaruh dan sebagainya, yang mampu menggerakkan hati orang lain dan sugesti mempunyai peranan yang sangat penting di dalam memelihara dan membina harga diri serta rasa pengabdian, partisipasi, dan rasa kebersamaan diantara parabawahan.

c. Mendukung tujuan. Tercapainya tujuan organisasi tidak secara otomatis terbentuk, melainkan harus didukung oleh adanya kepemimpinan. Oleh karena itu, agar setiap organisasi dapat efektif dalam arti mampu mencapai tujuan yang telah ditetapkan, maka setiap tujuan yang ingin dicapai perlu disesuaikan dengan keadaan organisasi serta memungkinkan para bawahan untuk bekerja sama.

d. Katalisator. Seorang pemimpin dikatakan berperan sebagai katalisator, apabila pemimpin itu selalu dapat meningkatkan segala sumber daya manusia yang ada, berusaha memberikan reaksi yang menimbulkan semangat dan daya kerja cepat semaksimal mungkin.

e. Menciptakan rasa aman. Setiap pemimpin berkewajiban menciptakan rasa aman bagi para bawahannya. Dan ini hanya dapat dilaksanakan apabila setiap pemimpin mampu memelihara hal-hal yang positif, sikap optimisme di dalam menghadapi segala permasalahan, sehingga dalam melaksanakan tugas-tugasnya, bawahan merasa aman, bebas dari 
segala perasaan gelisah, kekhawatiran, merasa memperoleh jaminan keamanan dari pimpinan.

f. Sumber inspirasi. Seorang pemimpin pada hakikatnya adalah sumber semangat bagi para bawahannya.Oleh karena itu, setiap pemimpin harus selalu dapat membangkitkan semangat para bawahan sehingga bawahan menerima dan memahami tujuan organisasi dengan antusias dan bekerja secara efektif ke arah tercapainya tujuan organisasi.

g. Bersikap menghargai. Setiap orang pada dasarnya menghendaki adanya pengakuan dan penghargaan diri pada orang lain. Demikian pula setiap bawahan dalam organisasi memerlukan adanya pengakuan dan penghargaan dari atasan. Oleh karena itu, menjadi suatu kewajiban bagi pemimpin untuk mau memberikan penghargaan atau pengakuan dalam bentuk apapun kepada bawahannya.

Berdasarkan uraian-uraian tersebut, maka dapat disimpulkan bahwa kepemimpinan adalah proses mempengaruhi, menggerakkan, mengarahkan, mendorong, dan mengajak orang lain untuk bekerja samadan mau bekerja secara produktif guna pencapaian tujuan tertentu.

\section{Faktor-Faktor yang Mempengaruhi Kepemimpinan}

Pelaksanaan tugas kepemimpinan mempengaruhi orang atau kelompok menuju tujuan tertentu, kita pemimpin, dipengaruhi oleh beberapa faktor. Faktorfaktor yang mempengaruhi kepemimpinan adalah sebagai berikut:

a. Faktor Kemampuan Personal. Pengertian kemampuan personal adalah kombinasi antara potensi sejak pemimpin dilahirkan ke dunia sebagai manusia dan faktor pendidikan yang ia dapatkan. Jika seseorang lahir dengan kemampuan dasar kepemimpinan, ia akan lebih hebat jika mendapatkan perlakuan edukatif dari lingkungan, jika tidak, ia hanya akan menjadi pemimpin yang biasa dan standar. Sebaliknya jika manusia lahir tidak dengan potensi kepemimpinan namun mendapatkan perlakuan edukatif dari lingkunganya akan menjadi pemimpin dengan kemampuan yang standar pula. Dengan demikian antara potensi bawaan dan perlakuan edukatif lingkungan adalah dua hal tidak terpisahkan yang sangat menentukan hebatnya seorang pemimpin.

b. Faktor Jabatan. Pengertian jabatan adalah struktur kekuasaan yang pemimpin duduki.Jabatan tidak dapat dihindari terlebih dalam kehidupan modern saat ini, semuanya seakan terstrukturifikasi. Dua orang mempunyai kemampuan kepemimpinan yang sama tetapi satu mempunyai jabatan dan yang lain tidak maka akan kalah pengaruh. samasama mempunyai jabaan tetapi tingkatannya tidak sama maka akan mempunyai pengarauh yang berbeda.

c. Faktor Situasi dan Kondisi. Pengertian situasi adalah kondisi yang melingkupi perilaku kepemimpinan. Disaat situasi tidak menentu dan kacau akan lebih efektif jika hadir seorang pemimpin yang karismatik. Jika kebutuhan organisasi adalah sulit untuk maju karena anggota organisasi yang tidak berkepribadian progresif maka perlu pemimpin transformasional. Jika identitas yang akan dicitrakan oragnisasi adalah religiutas maka kehadiran pemimpin yang mempunyai kemampuan kepemimpinan spritual adalah hal yang sangat signifikan. Begitulah situasi berbicara, ia juga memilah dan memilih kemampuan para pemimpin, apakah ia hadir disaat yang tepat atau tidak.

\section{Konsep Partisipasi Masyarakat}

Partisipasi masyarakat di dalam setiap proses pembuatan kebijakan publik merupakan hal penting sebagai cermin asas demokrasi di suatu negara. Prinsip partisipasi dalam upaya mewujudkan good governance yang dilakukan melalui pembangunan infrastruktur jalan sangat sejalan dengan pandangan baru yang berkembang di dalam partisipasi masyarakat dengan cara melihat masyarakat tidak hanya sebagai penonton melainkan sebagai masyarakat yang 
memiliki jiwa, membantu dan mau bekerja sama dalam pembanguan yang ada di dalamnya(owner ). (Adisasmita, 2010:4). Menurut Nurman ( 2015:252 ) Partisipasi masyarakat adalah keikutsertaan masyarakat dalam pengambilan keputusan, pemanfaatan sumber daya, pemecahan masalah yang berkaitan dengan pembangunan desa.H.A.R. Tilaar (2009:287) mengungkapkan partisipasi adalah sebagai wujud dari keinginan untuk mengembangkan demokrasi melalui proses desentralisasi dimana diupayakan antara lain perlunya perencanaan dari bawah (button-up) dengan mengikutsertakan masyarakat dalam proses perencanaan dan pembangunan masyarakat. Isbandi ( dalam Mustanir dan Rais, 2017: 5) mengatakan bahwa pengembangan konsep dan asumsi dasar untuk meluangkan gagasan dan praktis tentangpartisipasi masyarakat meliputi:

a. Partisipasi adalah hak dalam berpolitik yang melekat pada masyarakat seperti hak politik lainya. Hak itu tidak akan hilang ketika masyarakat memberikan kepercayaan pada orsng lain untuk duduk dalam instansi pemerintahan. Sedangkan hak dalam berpolitik yaitu hak asasi yang melekat pada setiap individu yang terkait

b. Partisipasi langsung dalam pengambilan keputusan tentang kebijakan masyarakat di instansi pemerintahan dapat menutupi kegagalan dalam demokrasi rakyat. Demokrasi rakyat masih meninggalkan beberapa kekurangan yang ditandai dengan adanya keraguan sejauh mana orang yang dipilih dapat menampilkan keinginan masyarakat

c. Partisipasi masyarakat yang dilakukan secara langsung dalam pengambilan keputusan masyarakat dapat memunculkan keterlibatan masyarakat yang lebih bermakna.

d. Partisipasi dilakukan secara teratur, bukan dengan cara kebetulan.

e. Berkaitan dengan penyerahan kewenangan sebagai alat yang mendorong tata pemerintahan yang baik (good governance).

f. Partisipasi masyarakat dapat menambah Kepercayaan masyarakat terhadap penyelenggara pemerintahan. Demokratisasi dan penyerahan kewenangan di Negara berkembang termasuk Indonesia terjadi dalam keadaan kurangnya kepercayaan masyarakat terhadap penyelenggaraan pemerintah.

Berikut ini dikemukakan beberapa alasan mengapa partisipasi itu penting dalam proses pembanguna desa (wahjudin, 2010) dalam (Nurman2015):

a. Partisipasi dalam praktik yang sederhana telah lama terbangun dalam pemahaman,kesadaran dan kehidupan masyarakat.

b. Partisipaisi memungkinkan perubahan yang lebih besar dalam cara berpikir, bersikap dan bertindak manusia. Hal ini sulit dilakukan jika perubahan ini hanya dilakukan oleh sebagian kecil atau kelompok tertentu yang tidak terlibat langsung.

c. Pemecahan permasalahan dan pemenuhan kebutuhan masyarakat secara menyeluruh hanya dapat dilakukan melalui proses interaksi, kerja sama dan berbagai peran.Penggunaan sumber daya dan pelayanan bagi masyarakat tidak dapat tercapai oleh gagasan yang dibangun oleh pemerintah atau pengambil kebijakan saja,karena sumber daya pendukung lebih banyak dimiliki oleh individu,kelompok atau organisasi masyarakat. Oleh karena itu konstribusi dan kerangka mekanisme pelayanan harus melibatkan masyarakat sebagai pemilik dan pengguna pelayanan itu.

d. Partisipasi merupakan suatu proses pelibatan orang lain terutama kelompok masyarakat yang terkena langsung untuk merumuskan masalah dan mencari solusi secara bersama.

e. Masyarakat memiliki informasi yang sangat penting untuk merencanakan program yang lebih baik,termasuk tujuan, pengetahuan,situasi,struktur sosial dan pengalaman menggunakan teknologi untuk kepentingannya. 
f. Masyarakat akan lebih termotivasi untuk bekerja sama dalam program pembangunan,jika ikut terlibat dan bertanggung jawab di dalamnya.

g. Dalam kehidupan demokrasi,secara umum masyarakat menerima bahwa mereka berhak berpartisipasi dalam keputusan mengenai tujuan dan harapan yang ingin dicapai.

h. Banyak permasalahan pembangunan dibidang pertanian, kesehatan, ekonomi, pendidikan dan kelembagaan yang tidak mungkin dipecahkan dengan pengambilan keputusan perorangan. Partisipasi kelompok sasaran dalam keputusan kolektif sangat dibutuhkan.

Keberhasilan pembangunan nasional pada umumnya dan pembangunan desa pada khususnya tidak saja ditentukan oleh pemerintah dan aparatnya melainkan juga oleh besarnya pengertian,kesadaran dan partisipasi seluruh lapisan masyarakat. Partisipasi adalah mengambil bagian atau turut menyusun,turut melaksanakan dan turut bertanggung jawab. Mencermati kedua kutipan tersebut, maka dapat kita ketahui ada enam hal yang pokok yang perlu kita kembangkan bila ingin memperoleh partisipasi masyarakat, dalam pembangunan, Adapun keenam hal tersebut adalah kesadaran,minat,kreatifitas, merencanakan atau menyusun dan melaksanakan. Apabila keenam hal tersebut dimiliki oleh masyarakat maka hal lain yang perlu diperhatikan adalah aspek kepemimpinan yang diterapkan oleh pemerintah desa beserta aparatnya didalam melaksanakan pembangunan di wilayahnya.

Kepemimpinan perlu dikemukakan disini karena antara partisipasi masyarakat dan kepemimpinan setempat tidak dapat dipisahkan satu sama lain dengan yang lainnya. Bila terpisahnya maka dengan sendirinya akan mengurangi atau bahkan kehilangan kekuatan. Misalnya partisipasi masyarakat besar,namun karena pemerintah desa tidak dapat menerapkan kepemimpinan yang sesuai dengan kondisi setempat,maka potensi tidak akan pernah diwujudkan seperti yang diharapkan.
Menurut Isbandi dalam Sahya Anggara (2014:223) bahwa partisipasi adalah keikutsertaan masyarakat dalam proses penggidentifikasian masalah dan potensi yang ada di masyarakat, pemilihan dan pengambilan keputusan tentang alternative solusi untuk menangani masalah, pelaksaan upaya mengatasi masalah, dan keterlibatan masyarakat dalam proses mengevaluasi perubahan yang terjadi. Pentingnya partisipasi masyarakat seperti yang dikemukakan pleh Conyers dalam (Sahya Anggara 2014:226), yaitu sebagai berikut:

a. Partisipasi masyarakat merupakan suatu alat untuk memperoleh informasi mengenai kondisi, kebutuhan, dan sikap masyarakat setempat yang tanpa kehadirannya program pembangunan serta proyek-proyek akan gagal.

b. Masyarakat akan lebih memercayai proyek atau program pembangunan jika merasa dilibatkan dalam proses persiapan dan perencanaanya.

c. Merupakan suatu hak demokrasi apabila masyarakat dilibatkan dalam pebangunan.

Hoofsteede dalam Khairuddin (1992:125), membagi partisipasi menjadi tiga tingkatan :

a. Partisipasi inisiasi (inisiation participation) adalah partisipasi yang mengundang inisiatif dari pemimpin desa, baik formal maupun informal, ataupun dari anggota masyarakat mengenai suatu proyek, yang nantinyaproyek tersebut merupakan kebutuhan bagi masyarakat.

b. Partisipasi legitimasi (legitimation participation) adalah partisipasi pada tingkat pembicaraan atau pembuatan keputusan tentang proyek tersebut.

c. Partisipasi eksekusi (execution participation) adalah partisipasi padatingkat pelaksanaan.

Pendapat lain dikemukakan oleh

Burt K. Schalan dan Roger (Widi Astuti 2011:27) bahwa manfaat dari partisipasi adalah:

a. Lebih banyak komunikasi dua arah

b. Lebih banyak bawahan mempengaruhi keputusan

c. Manajer dan partisipasi kurang bersikap agresif 
d. Potensi untuk memberikan sumbangan yang berarti dan positif, diakui dalam derajat lebih tinggi.

Hoofsteede dalam Khairuddin (2010:125), membagi partisipasi menjadi tiga tingkatan :
a. Partisipasi
inisiasi
(inisiation

participation) adalah partisipasi yang mengundang inisiatif dari pemimpin desa, baik formal maupun informal, ataupun dari anggota masyarakat mengenai suatu proyek, yang nantinyaproyek tersebut merupakan kebutuhan bagi masyarakat.

d. Partisipasi legitimasi (legitimation participation) adalah partisipasi pada tingkat pembicaraan atau pembuatan keputusan tentang proyek tersebut.
e. Partisipasi eksekusi (execution participation) adalah partisipasi padatingkat pelaksanaan.

Upaya Kepala Desa Dalam

Meningkatkan Partisipasi Masyarakat

a. Memberikan Motivasi

Motivasi dalam hal pembangunan desa sangat diperlukan dalam rangka menggerakkan masyarakat untuk ikut berpartisipasi dalam pelaksanaan pembangunan di desanya. Seorang Kepala Desa selaku pemimpin formal di desa harus mampu menggerakkan, mendorong dan memberikan motivasi kepada masyarakat untuk ikut berpartisipasi dalam setiap kegiatan yang berhubungan dengan pembangunan, karena tujuan dari pembangunan itu tidak akan dapat terwujud apabila tidak ada keterlibatan masyarakat didalamnya. Motivasi adalah sebagai keseluruhan proses pemberian dorongan bekerja kepada para bawahan sedemikian rupa sehingga mereka mau bekerja dengan ikhlas demi tercapainya tujuan organisasi dengan efisien dan ekonomis

\section{b. Melaksanakan Koordinasi dan Komunikasi}

Koordinasi mutlak diperlukan dalam sebuah organisasi, karena organisasi merupakan pelaksana fungsi manajemen dari seorang pemimpin dalam rangka menghimpun orang-orang, materi dan metode untuk bekerjasama ke arah pencapaian tujuan.

c. Pengawasan
Pengawasan ialah proses
pengamatan pelaksanaan seluruh kegiatan organisasi untuk menjamin agar pekerjaan yang sedang dilakukan berjalan sesuai dengan rencana yang telah ditentukan sebelumnya (Siagian, 2007, hal. 112). Kegiatan pengawasan diperlukan untuk mengetahui apakah pelaksanaan pekerjaan yang sedang dilaksanakan telah sesuai dengan apa yang telah direncanakan. $\mathrm{Di}$ dalam pembangunan desa, kegiatan pengawasan tidak hanya dilakukan oleh Kepala Desa dan perangkat desa sebagai pemerintah desa, tetapi juga dilakukan oleh seluruh masyarakat desa selaku pelaksana pembangunan.

d. Evaluasi

Kegiatan evaluasi jika dikaitkan dengan pembangunan merupakan suatu hal yang sangat penting yang harus dilakukan, karena kegiatan ini untuk mengetahui apakah pekerjaan atau pelaksanaan kegiatan pembangunan yang teah dilaksanakan sudah sesuai dengan rencana sebelumnya ataukah belum. Kegiatan evaluasi juga penting untuk mengetahui sejauh mana tingkat keberhasilan yang telah dicapai dalam kegiatan pembangunan tersebut, dan apabila terjadi kekurangan-kekurangan maka akan diperbaiki untuk kesempurnaannya. Dengan kata lain evaluasi adalah fungsi organik administrasi dan manajemen yang terakhir, atau dengan kata lain evaluasi ialah proses pengukuran dan pembandingan hasil-hasil yang seharusnya dicapai.

i. Partisipasi Masyarakat Dalam Pembangunan Desa

a. Perencanaan

Perencanaan adalah keseluruhan proses pemikiran dan penentuan secara matang tentang hal-hal yang akan dikerjakan di masa yang akan datang dalam rangka pencapaian tujuan yang telah ditentukan, partisipasi masyarakat dalam perencanaan pembangunan desa merupakan hal yang sangat penting dalam proses pembangunan, karena demi suksesnya pembangunan dan pencapaian hasil yang baik membutuhkan perencanaan yang 
matang untuk mendukung keberhasilan tersebut.

\section{b. Pelaksanaan}

Partisipasi ini diwujudkan dalam setiap kegiatan pembangunan yang dilaksanakan di desa, seluruh masyarakat hendaknya dilibatkan dalam setiap agenda pembangunan yang dilaksanakan di desanya tanpa kecuali, evaluasi pelaksanaan pembangunan maupun dalam kegiatan pekerjaan perbaikan hasil dari pembangunan tersebut.

c. Memelihara Hasil-hasil pembangunan

$$
\text { Wujud dari partisipasi }
$$

masyarakat dalam hal ini yaitu diharapkan masyarakat ikut menjaga dan memelihara semua hasil pembangunan di desanya dengan sebaik-baiknya, bukan sebaliknya merusak. Semua masyarakat desa hendaknya dapat memanfaatkan hasil pem-bangunan dengan baik, namun tidak hanya sebatas memanfaatkannya, tetapi juga ikut menjaga kelestariannya agar dapat dimanfaatkan untuk generasi yang akan datang.

$$
\text { Partisipasi }
$$

merupakan keikutsertaan masyarakat dalam penganbilan keputusan, pemanfaatan sumber daya dan pemecahan masalah yang berkaitan dengan pembangunan desa.

\section{Konsep Pembangunan}

Makna penting dari pembangunan adalah adanya kemajuan/perbaikan (progress), pertumbuhan dan diversifikasi.Secara sederhana pembangunan sering diartikan sebagai suatu upaya untuk melakukan perubahan menjadi lebih baik.Karena perubahan yang dimaksud adalah menuju arah peningkatan dari keadaan semula, tidak jarang pula ada yang mengasumsikan bahwa pembangunan adalah juga pertumbuhan.Seiring dengan perkembangannya hingga saat ini belum ditemukan adanya suatu kesepakatan yang dapat menolak asumsi tersebut. Akan tetapi untuk dapat membedakan keduanya tanpa harus memisahkan secara tegas batasannya, Siagian (2017) terhadap bukunya Administrasi Pembangunan mengemukakan, "Pembangunan sebagai suatu perubahan, mewujudkan suatu kondisi kehidupan bernegara dan bermasyarakat yang lebih baik dari kondisi sekarang, sedangkan pembangunan sebagai suatu pertumbuhan menunjukkan kemampuan suatu kelompok untuk terus berkembang, baik secara kualitatif maupun kuantitatif dan merupakan sesuatu yang mutlak harus terjadi terhadap pembangunan." Portes (2010) mendefenisiskan pembangunan sebagai transformasi ekonomi, sosial dan budaya. Pembangunan adalah proses perubahan yang direncanakan untuk memperbaiki berbagai aspek kehidupan masyarakat. Sedangkan Menurut Alexsander ( Norman 2015:88 ) Pembangunan proses perubahan yang dinrencanakan untuk memperbaiki berbagai aspek kehidupan masyarakat. Menurut Michael $P$ Todaro.(2015) mengungkapkan bahwa ada 3 Pembangunan yaitu:

a. Kecukupan (Sustnance) : kemampuan masyarakat untuk memahami bukan hanya kebutuhan dasar (Makanan) Melainkan mewakili semua hal yang merupakan kebutuhan dasar manusia secara fisik seperti pangan, sandan, papan, pendidikan, kesehatan, dan keamanan.

b. Jati diri (Self-Esteem): adanya dorongan dari jati diri sendiri untuk maju, untuk menghargai diri sendiri, untuk merasa diri pantas dan layak melakukan atau mengajarkan sesuatu dan seterusnya.

c. Kebebasan (Freedom): kemampuan untuk berdiri tegak di atas kaki sendiri (otonom) dan demokratis.

Pembangunan

bertujuan meningkatkan kesejahteraan masyarakat desa dan kualitas hidup manusia serta penanggulangan kemiskinan melalui pemenuhan kebutuhan dasar, pembangunan sarana dan prasarana desa, pengembangan potensi ekonomi local, serta pemanfaatan SDA dan lingkungan secara berkelanjutan.

Menurut Alexander ( dalam Nurman 2015 : 88 ) mengatakan bahwa proses perubahan yang direncanakan untuk memperbaiki berbagai aspek kehidupan masyarakat. 


\section{A. METODE PENELITIAN}

Penelitian ini akan di laksanakan di Desa Betao Kecamatan Pitu Riawa Kabupaten Sidenreng Rappang. Penelitian ini direncanakan berlangsung selama 2 (dua) bulan, dengan harapan bahwa lokasi penelitian tersebut, penulis dapat menemukan keadaan yang sebenarnya dari objek yang akan diteliti nantinya. Penelitian ini memiliki 2 variabel, yaitu variabel independen (bebas) dan variabel dependen (terikat). Vaiabel independen (bebas) yaitu kepemimpinan pemerintahan dan variabel dependen(teriakat) yaitu partisipasi masyarakat pada musyawarah perencanaan pembangunan di Desa Betao Kecamatan Pitu Riawa.

Populasi adalah wilayah generelisasi yang terdiri atas subjek objek yang mempunyai kuantitas dan karakteristik tertentu yang ditetapkan oleh peneliti untuk dipelajari dan kemudian ditarik kesimpulan (Sugiyono,2010:90). Menurut Margono dalam Ahmad (2015:137) Populasi adalah seluruh data yang menjadi perhatian kita dalam suatu ruang lingkup dan waktu yang kita tentukan. Jadi populasi merupakan objek atau subjek yang berada pada suatu wilayah dan memenuhi syarat-syarat tertentu yang mempunyai kaitan dengan masalah yang diteliti. Sedangkan yang dijadikan sebagai responden dalam penelitian ini sebesar 72 orang yaitu masyarakat yang mengikuti kegiatan MUSRENBANG. Adapun informan dalam penelitian ini Sekertaris kantor Desa Betao Kecamatan Pitu Riase Kabupaten Sidenreng Rappang.

Pengumpulan data yang seakurat mungkin mengenai variabel yang akan dikaji, peneliti menggunakan teknik yaitu Wawancara, Observasi, Kuesioner dan Studi Kepustakaan. Selanjutnya analisis data dalam penelitian ini akan dilakukan secara mendalam sebagai upaya mencari dan menata secara sistematis catatan hasil observasi. Wawancara dan informasi lainnya untuk meningkatkan pemahaman peneliti tentang kasus yang diteliti.Data yang telah dikumpulkan melalui wawancara, observasi, kosioner diolah dan dianalisis dengan menggunkan tehnik analisis deskriptif kuanitatif menggunakan bantuan tabel presentase, dengan menggunakan skala likert. Adapun tahapan-tahapan yang dilakukan penulis dalam analisis data adalah: Reduksi data, Tabulasi data Model Regresi dan Pengujian Hipotesis

\section{B. HASIL DAN PEMBAHASASAN}

1. Kepemimpinan

a. Bersifat adil

Hasil pengolahan data angka di atas menunjukkan bahwa dari 72 responden, ada 5 Orang atau 9,7\% responden mengatakan selalu, 5 orang atau $6.9 \%$ responden mengatakan sering, 12 orang atau $16,6 \%$ responden mengatakan kadang-kadang, 29 orang atau $40,2 \%$ respondenmengatakan Jarang, 19 orang atau $26 \%$ responden mengatakan Tidak Pernah, kemudian dari skor rata-rata di hasilkan persentase sebesar $46,6 \%$ yang termasuk kategori" Cukup Baik".

b. Memberi Sugesti

Dari hasil pengolahan data angka di atas menunjukkan bahwa dari 72 responden, ada 2 Orang atau 2,7\% responden mengatakan selalu, 6 orang atau $8,3 \%$ responden mengatakan sering, 10 orang atau $13,8 \%$ responden mengatakan kadang-kadang, 32 orang atau $44,4 \%$ respondenmengatakan Jarang, 22 orang atau $30,5 \%$ responden mengatakan Tidak Pernah, kemudian dari skor rata-rata di hasilkan persentase sebesar $41,6 \%$ yang termasuk kategori" Cukup Baik".

c. Mendukung Tujuan

Dari hasil pengolahan data angka di atas menunjukkan bahwa dari 72 responden, tidak ada responden yang mengatakan jawaban selalu, tidak ada responden yang mengatakan jawaban sering, 22 orang atau 30,5\% responden mengatakan kadang-kadang, 24 orang atau $33,3 \%$ respondenmengatakan Jarang, 26 orang atau $36,1 \%$ responden mengatakan Tidak Pernah, kemudian dari skor rata-rata di hasilkan persentase sebesar $41,38 \%$ yang termasuk kategori" Cukup Baik".

d. Katalisator 
Dari hasil pengolahan data angka di atas menunjukkan bahwa dari 72 responden, ada 5 Orang atau 6,9\% responden mengatakan selalu, 6 orang atau $8,3 \%$ responden mengatakan sering, 14 orang atau $19,4 \%$ responden mengatakan kadang-kadang, 28 orang atau $38,8 \%$ respondenmengatakan Jarang, 19 orang atau 26,3\% responden mengatakan Tidak Pernah, kemudian dari skor rata-rata di hasilkan persentase sebesar $46,1 \%$ yang termasuk kategori" Cukup Baik".

e. Menciptakan Rasa aman

Dari hasil pengolahan data angka di atas menunjukkan bahwa dari 72 responden, ada 6 Orang atau $8,3 \%$ responden mengatakan selalu, 17 orang atau $23,6 \%$ responden mengatakan sering, 18 orang atau $25 \%$ responden mengatakan kadang-kadang, 19 orang atau $26,3 \%$ respondenmengatakan Jarang, 12 orang atau $16,6 \%$ responden mengatakan Tidak Pernah, kemudian dari skor rata-rata di hasilkan persentase sebesar $56,1 \%$ yang termasuk kategori" Cukup Baik".

f. Sumber Inspirasi

Dari hasil pengolahan data angka di atas menunjukkan bahwa dari 72 responden, ada 12 Orang atau 16,6\% responden mengatakan selalu, 3 orang atau $4,1 \%$ responden mengatakan sering, 22 orang atau $30,5 \%$ responden mengatakan kadang-kadang,24 orang atau $33,3 \%$ respondenmengatakan Jarang, 11 orang atau $15,2 \%$ responden mengatakan Tidak Pernah, kemudian dari skor rata-rata di hasilkan persentase sebesar $52,22 \%$ yang termasuk kategori" Cukup Baik".

g. Bersifat Menghargai

Dari hasil pengolahan data angka di atas menunjukkan bahwa dari 72 responden, ada 19 Orang atau $26,3 \%$ responden mengatakan selalu, 7 orang atau $9,7 \%$ responden mengatakan sering, 24 orang atau $33,3 \%$ responden mengatakan kadang-kadang, 19 orang atau $26,3 \%$ respondenmengatakan Jarang, 3 orang atau $4,1 \%$ responden mengatakan Tidak Pernah, kemudian dari skor rata-rata di hasilkan persentase sebesar $62,22 \%$ yang termasuk kategori "Terlaksana dengan Baik".

Berdasarkan hasil penelitian tersebut dapat ditarik kesimpulan bahwa hasil yang diperoleh dari pernyataan yang mengenai kepemimpinan yang bersifat adil di kategorikan "Cuku Baik" dengan hasil presentase $46,6 \%$ yang berartibahwa responden menyatakan kepala desa sudah dapat memberikan keadilan dalam pembangunan dan pembaharuan disetiap dusun yang ada di desa betao, namun perlu di tingkatkan lagi agar pembangunan di setiap dusun terlaksana lebih baik lagi. Hasil penelitian tersebut dapat ditarik kesimpulan bahwa hasil yang diperoleh dari pertanyaan yang mengenai kepemimpinan yang memberi sugesti dikategorikan "Cukup Baik" dengan hasil presentase 41,6 yang berarti bahwa Kepala Desa harus lebih mempengaruhi masyarakat supaya mereka mau diarahkan untuk mencapai tujuan pembangunan agar masyarakat juga merasa mempunyai tanggung jawab dengan pembangunan yang ada di desa.

Hasil penelitian tersebut dapat ditarik kesimpulan bahwa hasil yang diperoleh dari pertanyaan yang mengenai kepemimpinan yang mendukung tujuan dikategorikan "Cukup Baik" dengan hasil presentase $41,38 \%$ yang berarti bahwa kepala desa bertanggung jawab dalam mengoperasikan dan mengendalikan setiap program/kegiatan pembangunan yang di laksanakan dengan baik di desa Betao namun kepala desa perlu lebih meningkatkan pembangunan agar berjalan dengan efektif dan efesien. Berdasarkan hasil penelitian tersebut dapat ditarik kesimpulan bahwa hasil yang diperoleh dari pertanyaan mengenai kepemimpinan katalisator dikategorikan" Cukup Baik" dengan hasil presentase $46,1 \%$ yang berarti bahwa kepemimpinan sudah diterapkan dengan baik namun perlu di tingkatkan lebih lagi terutama pada pembangunan partisipasi masyrakat. Hasil penelitian tersebut dapat ditarik kesimpulan bahwa hasil yang diperoleh dari pertanyaan mengenai kepemimpinan yang menciptakan rasa aman dikategorikan " Cukup Baik " dengan hasil presentase $56,1 \%$ yang 
berarti bahwa Kepala Desa Betao mampu memelihara hal-hal yang positif, sikap optimisme dalam menghadapi segala permasalahan pembangunan Berdasarkan hasil penelitian tersebut dapat ditarik kesimpulan bahwa hasil yang diperoleh dari pertanyaan yang mengenai kepemimpinan sumber ipirasi dikategorikan "Cukup Baik " dengan hasil presentase $52,22 \%$ yang berarti bahwa kepala desa betao harus selalu dapat membangkitkan semangat para masyarakat agar masyarakat bekerja secara efektif kearah tercapainya tujuan pembangunan. Berdasarkan hasil penelitian tersebut dapat ditarik kesimpulan bahwa hasil yang diperoleh dari pertanyaan yang mengenai kepemimpinan yang bersifat menghargai dikategorikan " Terlaksana dengan Baik " dengan hasil presentase $62,22 \%$ hal demikian dikarenakan Kepala Desa sadar akan tanggung jawabnya sebagai pemberi arahan kepada masyarakat.

Hasil di atas maka dapat di tarik kesimpulan bahwa indikator Kepemimpinan yaitu Bersifat Menghargai dengan nilai paling tinggi yaitu $62,22 \%$ di kategorikan "Terlaksana dengan baik " kemudian pada indikator Kepemimpinan yang paling rendah yaitu Memberi Sugesti dengan nilai $41,6 \%$ atau di kategorikan " Cukup Baik “. Berdasarkan uraian di atas maka dapat dinyatakan bahwa kepemimpinan pemerintahan di Desa Betao Kecamatan Pitu Riawa Kabupaten Sidenreng Rappang, jika dibandingkan dengan penelitian terdahulu yang dilakukan oleh Mia Arta Oktavia pada tahun 2018 dengan melihat teori yang digunkan berbeda, teori yang digunakan adalah Pathfinding (pencari alur), Alingning (penyelaras), Empowering (pemberdayaan) yang diajuhkan dalam teori kepemimpinan Covey dalam Rivai (2014:156), sedangkan penelitian ini menggunakan teori yaitu bersifat adil, memberi sugesti, mendukung tujuan, katalisator, menciptakan rasa aman, sumber inspirasi, besikap menghargai yang diajukan oleh Wahjosumidjo (Wijayanti,2012).

\section{Partisipasi Masyarakat}

a. Partisipasi inisiasi (inisiation participation)

Dari hasil pengolahan data angka di atas menunjukkan bahwa dari 72 responden, ada 5 Orang $6,9 \%$ responden mengatakan selalu,20 orang atau $27,7 \%$ responden mengatakan sering, 24 orang atau $33,3 \%$ responden mengatakan kadang-kadang, 20 orang atau $27,77 \%$ respondenmengatakan Jarang, 3 orang atau $4,1 \%$ responden mengatakan Tidak Pernah, kemudian dari skor rata-rata di hasilkan persentase sebesar $61,38 \%$ yang termasuk kategori" Terlaksana dengan Baik ".
b. Partisipasi legitimasi (legitimation participation)

Hasil pengolahan data angka di atas menunjukkan bahwa dari 72 responden, ada 7 Orang atau $9,7 \%$ responden mengatakan selalu, 20 orang atau $27,7 \%$ responden mengatakan sering, 27 orang atau $37,5 \%$ responden mengatakan kadang-kadang, 20 orang atau $27,7 \%$ respondenmengatakan Jarang, 7 orang atau $9,7 \%$ responden mengatakan Tidak Pernah, kemudian dari skor rata-rata di hasilkan persentase sebesar $67,5 \%$ yang termasuk kategori" Terlaksana dengan Baik ".

$$
\begin{aligned}
& \text { Cartisipasi eksekusi (execution } \\
& \text { participation) }
\end{aligned}
$$

Hasil pengolahan data angka di atas menunjukkan bahwa dari 72 responden, ada 3 Orang atau $4,1 \%$ responden mengatakan selalu, 15 orang atau $20,8 \%$ responden mengatakan sering, 32 orang atau 44,4\% responden mengatakan kadang-kadang, 19 orang atau $26,3 \%$ respondenmengatakan Jarang, 3 orang atau $4,1 \%$ responden mengatakan Tidak Pernah, kemudian dari skor rata-rata di hasilkan persentase sebesar $58,8 \%$ yang termasuk kategori" Cukup Baik". Hasil penelitian tersebut dapat ditarik kesimpulan bahwa hasil yang diperoleh dari pertanyaan yang mengenai partisipasi inisiasi dikategorikan Terlaksana dengan Baik" dengan hasil presentase $61,38 \%$ yang berarti bahwa responden berpartisipasi dalam menyumbangkan ide/gagasan dalam rancangan pembangunan yang menyangkutkan kesejahteraan mereka, 
dikarenakan sebagian besar jenjang pendidikan terakhir yaitu SMA ( Sekolah Menengah Atas ).

Berdasarkan hasil penelitian tersebut dapat ditarik kesimpulan bahwa hasil yang diperoleh dari pertanyaan mengenai partisipasi legitimasi dikategorikan "Terlaksana dengan Baik " dengan hasil presentase $67,5 \%$, hal ini dikarenakan Kepalan Desa mampu merima usulan dari masyarakat tentang hal pembangunan di Desa. Hasil penelitian tersebut dapat ditarik kesimpulan bahwa hasil yang diperoleh dari pertanyaan mengenai partisipasi eksekusi dikategorikan "Cukup Baik" dengan hasil presentase $58,8 \%$, hal ini dikarenakan kepala desa mampu memberikan arahan kepada masyarakat terkait pembangunan di desa namun kepala Desa perlu meningkatkan lagi arahan/motipasi kepada masyarakat agar pembangunan dapat bejalan dangan efekti dan efesian.

Dari hasil yang di peroleh di atasa maka dapat di tarik kesimpulan bahwa indikator Partisipasi Masyarakat yaitu sebagai partisipasi legitimasi dengan nilai persentase paling tinggi yaitu $67,5 \%$ di kategorikan " Terlaksana dengan baik " kemudian pada indikator Partisipasi Masyarakat yang paling rendah yaitu Partisipasi eksekusi dengan nilai persentase $58,8 \%$ atau di kategorikan "Terlaksana dengan baik ".

Berdasarkan uraian di atas, maka dapat dinyatakan bahwa mengenai Partisipasi Masyarakat Pada Musyawarah Perencanaan Pembangunan di Desa Betao Kecamatan Pitu Riawa Kabupaten Sidenreng Rappang. jika dibandingkan dengan penelitian terdahulu yang di lakukan oleh Mia Arta Oktavia pada tahun 2018 dengan melihat teori yang digunakan berbeda teori yang digunakan adalah partisipasi itu dilakukan melalui organisasi yang sudah ada pada masyarakat, partisipasi memberikan manfaat langsung, manfaat yang diperoleh memenuhi kepentingan masyarakat, adanya kontrol yang dilakukan masyarakat yang di ajukan oleh Goldsmith dan Blustain dalam Ndraha (1990:105), sedangkan penelitian ini menggunakan teori partisipasi inisiasi, partisipasi legitimasi, partisipasi eksekusi yang di ajukan oleh Hoofsteede dalam Khairuddi.

3. Analisis Regresi Sederhana yaitu pengaruh $X$ terhadap $Y$ dengan menggunakan SPSS.

a. Variabel Pengaruh Kepemimpinan (X)

Berdasarkan tabel hasil olah data diatas, terkait dengan variabel pengaruh kepemimpinan $(\mathrm{X})$, diketahui bahwa kolom $\mathrm{N}$ menunjukkan responden sebanyak 72 orang, kolom Minimum menunjukkan bobot nilai terendah yaitu 1 , kemudian kolom Maximum menunjukkan bobot nilai tertinggi yaitu 5, dan kolom Sum menunjukkan jumlah keseluruhan dari nilai pertanyaan per-item yakni: 168, 150, 140, 166, 202, 188, 224. Dan kolom Mean menunjukkan jumlah keseluruhan dari nilai pertanyaan per-item yakni 2.33, 2,08, 1.94, 2.31, 2.81, 2.63, 3.11. Maka hasil olah data SPSS, dinyatakan Valid.

b. Variabel Partisipasi Masyarakat

Berdasarkan tabel hasil olah data diatas, terkait dengan variabel partisipasi masyarakat (Y), diketahui bahwa kolom $\mathrm{N}$ menunjukkan jumlah responden sebanyak 72 orang, kolom Minimum menunjukkan bobot nilai terendah yaitu 1 , kemudian kolom Maximun menunjukkan bobot nilai tertinggi yaitu 5, dan kolom Sum menunjukkan jumlah keseluruhan dari nilai pertanyaan per-item yakni : 220, 227, 220. Dan kolom Mean menunjukkan jumlah keseluruhan dari nilai pertanyaan per-item yakni: $3.06,3.15,3.06$. Maka hasil olah data SPSS, dinyatakan Valid.

c. Uji Kualitas Data

Untuk menguji kualitas data dilakukan dengan uji validitas dan uji reliabilitas. Uji validitas adalah suatu ukuran yang menunjukkan yang menunjukkan tingkat kevalidan atau kesahihan suatu instrumen. Sebuah instrumen dikatakan valid apabila dapat mengungkapkan data dari variabel yang diteliti. Model pengujian menggunakan pendekatan korelasi item-total dikoreksi (corrected item-total correlation) untuk menguji validitas internal setiap item pernyataan kuesioner yang disusun dalam bentuk skala. Untuk menentukan apakah sebuah item dinyatakan valid atau tidak 
maka para ahli menetapkan patokan besaran koefisien korelasi item total dikoreksi sebesar 0,25 atau 0,30 sebagai batas minimal valid tidaknya sebuah ítem. Artinya,sama atau lebih besar dari 0,25 atau 0,30 mengindikasikan item tersebut memiliki validitas yang memadai (Kusnendi, 2008:96). Dapat dilihat pada tabel 22 sebagai berikut:

\section{d. Variabel Kepemimpinan (X)}

Berdasarkan tabel hasil olah data di atas, diketahui bahwa 72 dari 7 item pertanyaan yang digunakan untuk mengukur variabel Kepemimpinan Kepala Desa dinyatakan valid dengan nilai corrected item-total correlation lebih besar dari $>0.25,0.30$ ( corrected item-total correlation $>0.25, \quad 0.30$ ). Sedangkan uji reliabilitas adalah alat untuk mengukur konsistensi jika jawaban seseorang terhadap suatu kuisioner yang merupakan indikator dari variabel atau konstruk. Suatu kuisioner dikatakan relibel atau handal pertanyaan adalah konsisten atau stabil dari waktu ke waktu. Suatu konstruk atau variabel dikatakan relibel jika memberikan nilai Cronbach Alpha $\geq 0.60$. (Ghozali, 2009).

\section{e. Variabel Partisipasi Masyarakat (Y)}

Berdasarkan tabel hasil olah data di atas, diketahui bahwa 72 dari 3 item pertanyaan yang digunakan untuk mengukur variabel Kepemimpinan Kepala Desa dinyatakan valid dengan nilai corrected item-total correlation lebih besar dari $0.25,0.30$ ( corrected item-total correlation $>0.25,0.30$ ).

\section{f. Uji Asumsi Klasik}

Uji normalitas model dapat dideteksi dengan melihat penyebaran data ( titik) pada sumbu diagoanal dari grafik $P$ P Plot (Ghozali, 2009). P-P Plot hasil olah data, maka model regresi dalam penelitian ini memenuhi asumsi normalitas dilihat dari data yang menyebar disekitar garis diagonal dan mengikuti arah garis diagonal, atau grafik histogramnya menunjukkan pola distribusi normal, maka regresi memenuhi asumsi normalitas.

\section{g. Model Regresi dan Pengujian Hipotesis}

Tabel Coefficients hasil olah data, maka model regresi yang digunakan dalam penelitian ini untuk mengukur Pengaruh Kepemimpinan terhadap Partisipasi Masyarakat dalam Pembangunan, dapat dianalisa berdasarkan koefesien-koefesien sebagai berikut:

$$
\mathrm{Y} 1=9.011+0.15 \mathrm{X}
$$

Dari fungsi regresi di atas, maka dapat dijelaskan:

a. Konstanta sebesar 9.011, menyatakan bahwa nilai konsisten variabe partisipasi adalah sebesar 9.011.

b. Nilai koefisien regresi $X$ sebesar 0.15 , menyatakan bahwa setiap penambahan $1 \%$ nilai $B$ maka nilai partisipasi bertambah sebesar 0.15 , koefisien regresi tersebut bernilai positif sehingga dapat dikatakan bahwa arah pengaruh variabel kepemimpinan $(X)$ terhadap variabel Partisipasi Masyarakat (Y) adalah positif.

Berdasarkan nila signifikansi dari tabel Coeficients diperoleh nilai signifakansi sebesar $0,000<$ probabilitas 0,05 , sehingga dapat disimpulkan bahwa variabel kepemimpinan $(X)$ berpengaruh terhadap partisipasi masyarakat $(Y)$.

\section{h. Anova}

Hasil dari uji ANOVA pada bagian ini ditampilkan hasil yang diperoleh adalah nilai $\mathrm{F}=0.80$ dengan tingkat probabilitas sig. 0.000 . oleh karena probabilitas (0.000) jauh lebih kecil dari 0.05, maka model regresi bisa dipakai untuk memprediksi kinerja. Untuk menguji kebenaran hipotesis dalam penelitian ini dilakukan uji $F$. Untuk mengetahui bahwa ada pengaruh/Signifikan dapat diketahui dengan melihat dari level of significant $\alpha=$ 0,05 . Jika nilai signifikansi lebih kecil dari 0.05 maka Ho ditolak dan $\mathrm{Ha}$ diterima. Berdasarkan hasil olah data pada tabel ANOVA, maka diketahui nilai $F_{\text {hitung }}$ yang diperoleh sebesar 0.80 dengan tingkat signifikan $0.000 \quad(F<0,05)$ yang berarti bahwa variabel kepemimpinan mempunyai pengaruh/signifikan terhadap variabel partisipasi masyarakat. 
Uji statistik $t$ untuk menunjukkan seberapa jauh pengaruh satu variabel penjelas/independen secara individual menerangkan variasi variabel dependen berdasarkan tabel coefficients hasil olah data SPSS, maka diketahui bahwa:

$$
\begin{array}{ll}
\text { a. Nilai } t_{\text {hitung }} & \text { variabel } \\
\text { kepemimpinan } & (X) 9.850 \\
\text { dengan tingkat signifikansi } & \\
0.000 \text {. } & \\
\text { b. } & \text { Hipotesis berdasarkan uji } t \\
& \text { dirumuskan secara statistik } \\
\text { berikut. } \\
\text { Ha }: P_{y x} \neq 0 \\
\text { Ho }: P_{y x} \neq 0
\end{array}
$$

\section{Hipotesis bentuk kalimat :}

a. Hipotesis $\mathrm{Ha}$ : Kepemimpinan berpengaruh/Signifikan terhadap Partisipasi Masyarakat pada musyawarah perencanaan Pembangunan di Desa Betao Kecamatan Pitu Riawa Kabupaten Sidenreng Rappang.

b. Hipotesis Ho : Kepemimpinan tidak berpengaruh/Signifikan terhadap Partisipasi Masyarakat pada musyawarah perencanaan Pembangunan di Desa Betao Kecamatan Pitu Riawa Kabupaten Sidenreng Rappang.

\section{Kaidah keputusan :}

a. Jika nilai $\mathrm{t}$ hitung $\geq \mathrm{t}$ tabel, Maka Ho ditolak dan $\mathrm{Ha}$ diterima, artinya Signifikan

b. Jika nilai $\mathrm{t}$ hitung $\leq \mathrm{t}$ tabel, Maka Ho diterima dan Ha ditolak, artinya tidak Signifikan

Tabel Coefficients diproleh $\mathrm{t}$ hitung $=9.850$ prosedur mencari statistik

tabel dengan kriteria.

a. Tingkat signifikan $(a=0,05)$ untuk uji dua pihak

b. df atau $\mathrm{dk}$ (derajat kebebasan) = Jumlah data -2 atau $72-2=70$

c. sehingga didapat $t_{\text {tabel }}=1,99$

Keputusan :

Ternyata nilai $\mathrm{t}$ hitung $>\mathrm{t}$ tabel, 9.850atau >1,99, maka $\mathrm{HO}$ ditolak dan $\mathrm{Ha}$ diterima,artinya signifikan. Jadi,
Kepemimpinan berpengaruh/signifikan terhadap Partisipasi Masyarakat pada Musyawarah Perencanaan Pembangunan di Desa Betao Kecamatan Pitu Riawa Kabupaten Sidenreng Rappang.

\section{KESIMPULAN}

Berdasarkan dengan hasil penelitian maka adapun Simpulan yang dapat kami kemukakan adalah sebagai berikut :

1. Dari hasil analisis oleh data frekuensi yang dilakukan, maka dapat disimpulkan berdasarkan tanggapan responden yang menunjukkan bahwa kepemimpinan di Desa Betao Kecamatan Pitu Riawa kabupaten sidenreng rappang dengan nilai persentase sebesar 49,46\% dengan kategori " Cukup Baik".

2. Dari hasil analisis oleh data frekuensi yang dilakukan, maka dapat disimpulkan berdasarkan tanggapan responden yang menunjukkan bahwa Partisipasi Masyarakat di Desa Betao Kecamatan Pitu Riawa kabupaten sidenreng rappang dengan nilai persentase sebesar $62,56 \%$ dengan kategori "Terlaksana dengan Baik".

3. Diketahui nilai $\mathrm{t}$ hitung $>\mathrm{t}$ tabel, 9.850atau >1,99, dapat disimpulkan bahwa variabel kepemimpinan pemrintahan berpengaruh/signifikan terhadap partisipasi masyarakat dalam pembangunan $(\mathrm{Y})$.

\section{REFERENSI}

Ahmad, Jamaluddin. 2015. Metode Penelitian Administrasi Publik (Teori dan Aplikasi): Gava Media. Yogyakarta.

Agustina, Widiastuti. 2011. Hubungan antara Kecerdasan Emosional dan Komitmen Kerja Karyawan Departemen F \& BProduct Hotel Satika Premier. Universitas Katalok Atmajaya: Tesis. Jakarta. 
Anggara, Sahya. 2014. Kebijakan Publik,: Pustaka Setia. Bandung.

Adisasmita, R. 2010. Pembangunan Kawasan dan Tata Ruang. Yogyakarta : graha Dham

H.A.R. Tilaar. 2009. Kekuasaan dan Pendidikan Manajemen Pendidikan Nasional Dalam Pusaran Kekuasaan. Jakarta. Rineka Cipta

Isbandi, Sahya Anggara. 2014. Perencanaan Partisipasi BerbasisAset Komunitas: dariPemikiran Menuju Penerapan FISIP UI Press. Depok

Kartini Kartono. 2014. Pemimpin dan Kepemimpinan: apakah Kepemimpinan abnormal itu. Raja Gravindo Persada. Jakarta.

Khaeruddin. Dkk, 2010. Kurikulum Tingkat Satuan Pendidikan Konsep dan Implementasinya. Pilar Media. Jakarta.

Moh. Nasir. 2015. Strategi Penelitian. Ghalia Indonesia. Jakarta.

Martono, Nanang. 2010. Metode Penelitian Kuantitatif. Jakarta :PT Raya Granfindo Persada.

Ikbal, Muhammad Dkk. Partisipasi Masyarakat dalam perencanaan pembangunan Desa Dongi Kecamatan Pitu Riase Kabupaten Sidenreng Rappang. Jurnal Wedana.2019: Volume 5 No.1: 581 -

588.https://doi.org/10.25299/wedan a.2019.vol5(1).3086

Mustanir, Ahmad \& Rais, M. Rahmat Razak. Oktober 2017. Nilai Sosial Budaya Pada Partisipasi Masyarakat Etnik Towani Tolalalng Dalam Muayawarah Rencana Pembangunan. Prosiding Konferensi Nasiaonal Ke-6
Asosiasi Program Pascasarjana Perguruan Tinggi Muhammadiayah Aisyiyah ( APPPTMA). Jilid 2. Sosial dan Politik, Pemikiran Islam, Hukum, Kesehatan. ISBN 978-602-50701-1-0. Penerbit Program Pascasarjana Universitas MuhammadiyahYokyakarta.

Cetakan 1. Hal 1-7.

Mustanir, Ahmad, Sandi Lubis, November 2017, Participatory Rural Appraisal In Deliberations Of Developmen Planning Proceedings. Publisher Atlantis Democracy, Accountability, and Governance ( ICODAG 2017). Part Of DSeries Advance in Social, Education and Humanities Research. IABN 978-94-6252-4156. ISSN 2352-5398. Doi: 10.2991/icodang-17.2017.60.Vol 163 hal 316-319.

Mustanir, Ahmad \& Razak, Muhammad Rais Rahmat. Oktober 2017. Nilai Sosial Budaya Pada Partisipasi Masyarakat Etnik Towani Tololong Dalam Musyawarah Perencana Pembangunan . (hal 2). Program Studi Ilmu Pemerintahan Stisip Muhammadiyah Rappang. Asosiasi Program Perguruan Tinggi Muhammadiyah' Aisyiyah (APPPTMA)

Nurman. 2015. Metedologi Penelitian. Ghalia Indonesia. Jakarta.

Rivai, Mulyadi. 2012. Kepemimpinan dan Perilaku Organisasi. PT Raja Gravindo Persada.

Rival Veithzal, Dedi Mulyadi. 2012. Kepemimpinan Dan PerilakuOrganisasiEdesi Ketiga. Jakarta: Raja Wali Pers 
Samad, Zainuddin. 2017. Teori-Teori Mutakhir Dalam Persektif Ilmu Administrasi Publik. Phinatama Media. Makassar

Sugiyono.2013. Metode Penelitian Kuantitatif Kualitatif dan $R$ dan D . Bandung: Alfabeta

Sugiyino, 2014. Metode Penelitian Kuantitatif, Kualilatif, dan $R \& D$. Alfabeta. Bandung.

Siagian P. Sondang. 2014. Teori Motivasi Dan Aplikasinya. Edisi 3. Pt. Rineka Cipta. Jakarta

Sugiyono. 2009. Metode Penelitian Administrasi.

Alfabeta.Bandung.

Sutrisno,Edi.2010. Manajemen Sumber Daya Manusi. Jakarta: Kencana Prenada Media Graup

Wijayanti, Tina Lukas. 2012. Analisis Kontribusi dan Proyeksi. Universitas Muhammadiyah Surakarta. Skripsi

Zainuddin. 2017. Teori-teori Mutakhir dalam perspektif ilmuadminitrasi publik. Penerbit Phinatana Media.

Nurman. 2015. Strategi Pembangunan Daerah.Pt Raja Grafindo Persada. Jakarta.

Undand-Undang No. 6 Tahun 2014 Tentang Desa.

Erika Sari. 2018. Pengaruh Kepemimpinan Terhadap Partisipasi masyarakat dalam pembangunan di Desa Botto Kecamatan Pitu Riase Kabupaten Sidenreng Rappang. 